\title{
Heat Energy Budget of the Polar Air-Mass Transformed over Kuroshio Region under the Situation of Strong Subsidence
}

\author{
By Kozo Ninomiya \\ Meteorological Research Institute, Tokyo, 166 \\ (Manuscript received 15 February 1977, in revised form 16 May 1977)
}

\begin{abstract}
The atmospheric heat energy budget over the Kuroshio region has been analysed for the period of polar air outbreak' (cold period for short) in AMTEX '75. The situations of this period are somewhat different from those in AMTEX '74 described in Ninomiya and Akiyama (1976).

Three undisturbed periods of polar air outbreak, i.e., Period I (25-27 February 1974), Period II (15-16 February 1975) and Period III (20-23 February 1975) are selected for comparison.

Period I is characterized by the weak subsidence of the polar air mass and large amount of precipitation $(\sim 5 \mathrm{~mm} /$ day $)$ from the cloud layer capped by the inversion layer which distinctly separates the northerly subinversion layer from westerlies aloft. Periods II and III are characterized by the non-precipitating cloud layer capped by the inversion existing in the thick subsiding polar air mass.

The large apparent heat and moisture sources in the subinversion layer are commonly found for the three periods. Significant differences among these periods are found in 175 $250 \mathrm{mb}\left(p^{*}\right)$ layer including the inversion base. In Period I, both apparent heat and moisture sources show rapid decrease above the inversion. In Periods II and III, maximum of apparent moisture source and maximum of apparent heat sink are found around the inversion base, which are accounted for by the evaporation from the top of the non-precipitating cloud layer.

The results of comparison evidently demonstrate the difference between the energy balance in the precipitating and non-precipitating cloud layers and the controlling influence of large-scale subsiding motions upon the thermodynamic process of the polar air-mass transformation.
\end{abstract}

\section{Introduction}

AMTEX '74 (14 27 February 1974) and AMTEX '75 (14 28 February 1975), the first and second phases of Air-Mass Transformation Experiment, were conducted over the Kuroshio region around the Nansei Islands of Japan. A primary objective of the experiment is to determine the rate of transfer of heat and water vapor from the ocean to the atmosphere and to clarify thermodynamic process of air-mass transformation.

The evaluation of the heat energy supplied from the sea to the atmosphere based on bulk aerodynamic method was made by Kondo (1976) for both AMTEX '74 and AMTEX '75. The evaluation based on the atmospheric heat energy budget calculations over a large domain $(\sim 600 \mathrm{~km} \times$ $400 \mathrm{~km}$ ) was made by Nitta (1976) for AMTEX '74 and by Murty (1976) for AMTEX '75. The similar but more detailed budget analysis over the subdivided AMTEX domains was performed by Ninomiya and Akiyama (1976) for the period of the polar air outbreak ("cold period", for short) in AMTEX '74.

Although various synoptic situations occurred during AMTEX '74 and AMTEX '75 (see Saito (1976) and Ninomiya (1976)), we will focus our attention on the cold period in the present paper. The amount of total heat energy evaluated for the cold period of AMTEX '74 by Nitta (1976), Ninomiya and Akiyama (1976) coincides well with that by Kondo (1976) ( 1200 ly/day). The amount evaluated by Murty (1976) for the cold 
period of AMTEX '75 indicates also good agreement with that by Kondo (1976) ( 1200 ly/day), while Bowen's ratio obtained by Murty $(\sim 0.9)$ was unreasonably large as compared with that by Kondo $(\sim 0.5)$. The vertical profiles of apparent heat and moisture sources presented by Murty for AMTEX' 75 are somewhat different from those obtained for AMTEX '74. The aforementioned comparisons suggest us that the further investigation on the cold period of AMTEX' 75 will be necessary.

It is intended in the present paper, first, to describe characteristic features of air-mass transformation in the cold period of AMTEX' 75 and second, to demonstrate the differences in thermodynamic situation of air-mass transformation under different large-scale synoptic conditions by comparing the result of budget calculation for AMTEX '75 with that for AMTEX ' 74 .

\section{Data}

The upper-air observation stations operated for AMTEX' 75 are identical with those for AMTEX '74. The blacked and open circles on the station map (Fig. 1) indicate rawinsonde and radiosonde stations, respectively. The observations were made at 6-hour intervals $(00,06,12$ and 18 GMT) throughout the experiment.

In the present analysis we adopt $p^{*}$-coordinate system, where $p^{*}$ is the position on the vertical axis in terms of pressure differential relative to the sea level, that is, $p^{*}=p_{s f c}-p$ (Rasmusson, 1971). As the basic data for the analysis, the values of necessary elements at the constant $p^{*}$ levels of $25 \mathrm{mb}$ interval are obtained from the

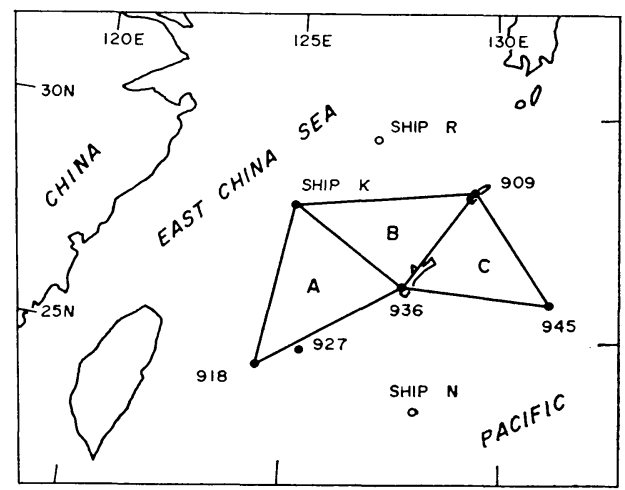

Fig. 1 Station map of upper-air observation. Blacked and white circles indicate rawinsonde and radiosonde stations respectively. Budget calculations are made over the areas $\mathrm{A}, \mathrm{B}$ and $\mathrm{C}$. original records by linear interpolation.

\section{Budget formulation and notation}

The budget formulation and notations used in the present analysis are same to those in the previous paper (Ninomiya and Akiyama (1976)), and thus, only the brief explanation is given here.

Vertical velocity $\omega^{*} \equiv d p^{*} / d t$ is obtained from equation of mass continuity as

$$
\omega^{*}\left(p^{*}\right)=-\int_{0}^{p^{*}} \nabla \cdot V d p^{*}
$$

The equations of heat and moisture averaged over a certain area are

$$
\frac{\delta T}{\delta t}+\frac{\partial}{\partial p^{*}}\left(\overline{\omega^{* \prime} T^{\prime}}\right)=d T_{R}+\frac{L}{d t}+\frac{C_{p}}{d t}
$$

and

$$
\frac{\delta q}{\delta t}+\frac{\partial}{\partial p^{*}}\left(\overline{\omega^{* \prime} q^{\prime}}\right)=-m
$$

where $(\delta T / \delta t)$ and $(\delta q / \delta t)$ are "grid-scale" individual changes of temperature and moisture, which also indicate apparent heat and moisture sources of the grid-scale motion. $\overline{d T_{R} / d t}, \overline{\omega^{* \prime} T^{\prime}}$, $\overline{\omega^{* \prime} q^{\prime}}$ and $m$ are net radiative cooling rate, eddy transport of heat, eddy transport of moisture and net condensation $(m=c-e ; c$ is condensation and $e$ is evaporation from clouds or precipitating particles) respectively. The individual changes of heat and moisture are evaluated as

$$
\begin{aligned}
\frac{\delta T}{\delta t}= & \frac{\partial T}{\partial t}+\overline{V \cdot V T} \\
& +\left[\bar{\omega}^{*} \frac{\partial \bar{T}}{\partial p^{*}}+\frac{R}{C_{p}} \frac{\bar{T}}{p}\left(\bar{\omega}^{*}-\bar{\omega}_{0}\right)\right]
\end{aligned}
$$

and

$$
\frac{\delta q}{\delta t}=\frac{\partial q}{\partial t}+\overline{V \cdot \nabla} \bar{q}+\bar{\omega}^{*} \frac{\partial \bar{q}}{\partial p^{*}}
$$

where $\omega_{o}$ is $(d p / d t)_{\mathrm{sfc}}$. have

By eliminating $m$ from eqs. (2) and (3), we

$$
\begin{aligned}
\frac{\delta}{\delta t}(T & \left.+\frac{L}{C_{p}} q\right) \\
& +\frac{\partial}{\partial p^{*}}\left(\overline{\omega^{* \prime} T^{\prime}}+\frac{L}{C_{p}} \overline{\omega^{* \prime} q^{\prime}}\right)=\frac{d T_{R}}{d t}
\end{aligned}
$$

where $\delta\left(T+L / c_{p} q\right) / \delta t$ is "apparent total heat energy source".

Integrating eqs. (2), (3) and (6) vertically from $p^{*}$ to $p^{*}$ top at which eddy (convective) transport vanishes, we evaluate the eddy flux of sensible, latent and total heat energy at $p^{*}$ as 


$$
\begin{aligned}
F_{S}\left(p^{*}\right) & \equiv \frac{C_{p}}{g} \overline{\omega^{* \prime} T^{\prime}} \\
& =\frac{C_{p}}{g} \int_{p^{*}}^{p^{*} \mathrm{top}}\left[\frac{\delta T}{\delta t}-\begin{array}{c}
d T_{R} \\
d t
\end{array}-\frac{L}{C_{p}} m\right] d p^{*} \\
F_{L}\left(p^{*}\right) & \equiv \frac{L}{g} \overline{\omega^{* \prime} q^{\prime}}=\frac{L}{g} \int_{p^{*}}^{p^{*} \mathrm{top}}\left(\frac{\delta q}{\delta t}+m\right) d p^{*}
\end{aligned}
$$

and

$$
\begin{aligned}
F_{C}\left(p^{*}\right) & \equiv \frac{1}{g} \cdot\left(C_{p} \overline{\omega^{* \prime} \overline{T^{\prime}}}+L \overline{\omega^{* \prime} q^{\prime}}\right) \\
& =\frac{C_{p}}{g} \int_{p^{*}}^{p^{*} \mathrm{top}}\left[\frac{\delta}{\delta t}\left(T+\frac{L}{C_{p}} q\right)-\frac{d T_{R}}{d t}\right] d p^{*}
\end{aligned}
$$

$F_{S}, F_{L}$ and $F_{c}$ at $p^{*}=0$ are, of course, rates of sensible, latent and total heat energy supply from the sea surface to the atmosphere, respectively.

Evaluations of eqs. (4) and (5) are performed over the three subdivided AMTEX areas, A, B and $\mathrm{C}$ indicated on Fig. 1 at 6-hour intervals.

\section{Features of the cold air mass of AMTEX '75}

\subsection{Gross description}

The vertical time sections of potential temperature $\theta$, equivalent potential temperature $\theta_{e}$, relative humidity and mixing ratio $q$ averaged
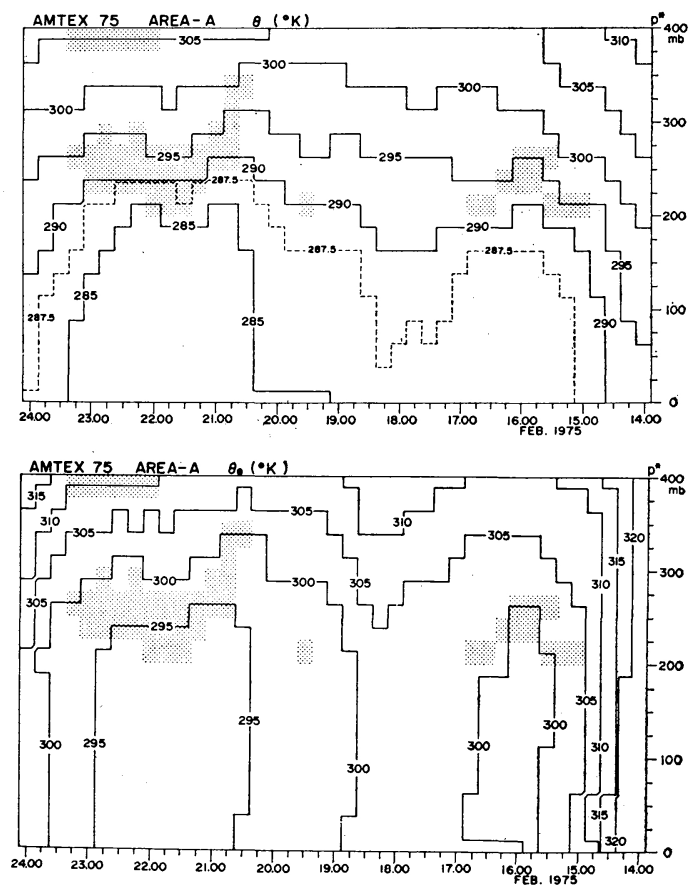
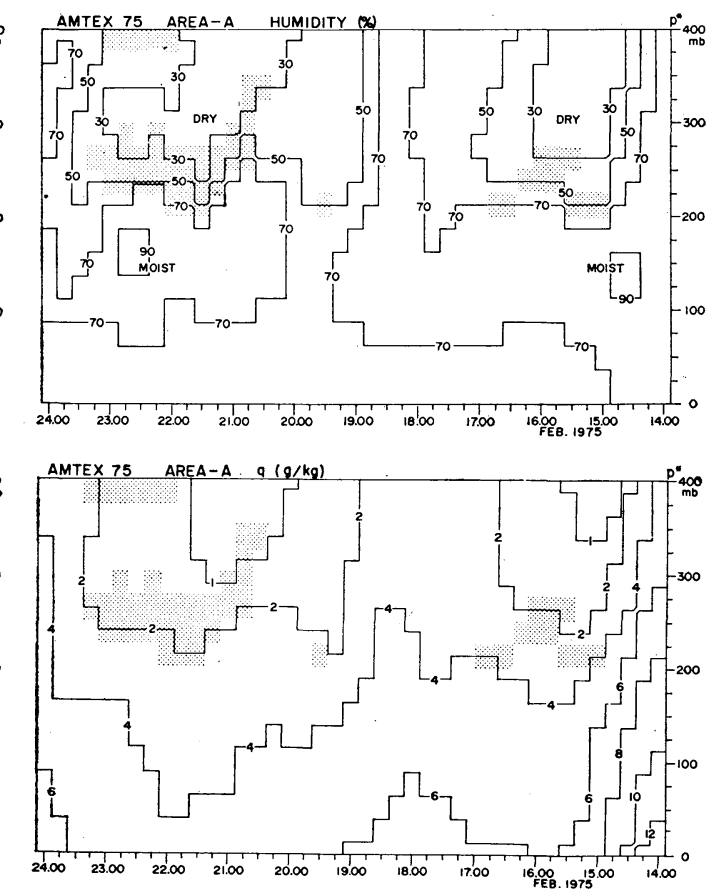

over area A are presented in Fig. 2, where stippled areas indicate the inversion layer.

A synoptic-scale cyclone associated with a westerly trough aloft rapidly developed on 14 February during its passage over AMTEX area. The high temperature and high humidity on 14 February are owing to warm and moist air advection prevailing in front of the cyclone. The strong polar air outbreak began after the passage of cyclone and then the "cold period" continued until 23, though the situation of outbreak was somewhat disturbed on 18 and 20 February when other cyclones passed to the north of AMTEX area. The polar air outbreak was especially intense in 14 16 and 20 23 February.

\subsection{Thermal structure of the cold air mass}

Fig. 3 is the vertical time section showing the inversion layer and the stable layer $(\partial T / \partial Z \geq$ $-0.2 \mathrm{C} / 100 \mathrm{~m}$ ) over area $A$. The inversion (or stable) layer exists throughout the analysed period except 17 18 February and its base is approximately at $200 \mathrm{mb}\left(p^{*}\right)$. The zone of stability associated with the inversion is centered approximately on $292 \mathrm{~K}$ isentrope over this area. The stratification of the subinversion layer is characterized by conditional instability, except the lowermost $25 \mathrm{mb}$ layer where the lapse rate is

Fig. 2 Vertical time section of potential temperature $\theta$, equivalent potential temperature $\theta_{e}$, relative humidity and mixing ratio $q$ over area A. Stipplings indicate the inversion layer over area $\mathrm{A}$. The abscissa indicates the date and the ordinate $p^{*}$. 


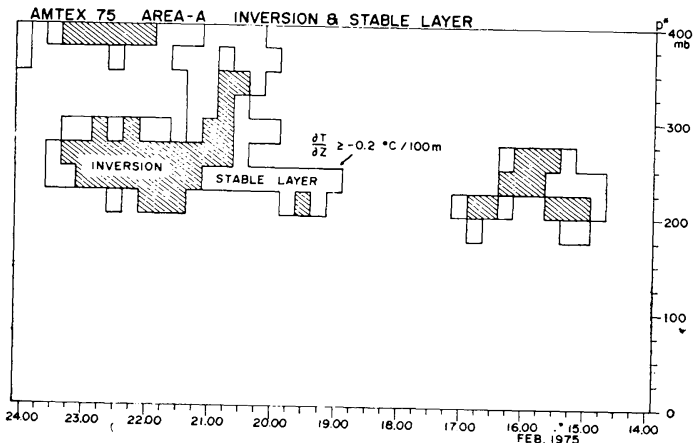

Fig. 3 Vertical time section showing the inversion and stable layers over area $A$. The abscissa indicates the date and the ordinate $p^{*}$.

super-adiabatic. As is shown in Fig. 2 the mixing ratio in the lower layer decreases from $10 \mathrm{~g} / \mathrm{kg}$ to $5 \mathrm{~g} / \mathrm{kg}$ when the polar air breaks out, and varies around $4 \mathrm{~g} / \mathrm{kg}$ during the analyzed period. Relative humidity as well as mixing ratio shows the rapid decrease within the inversion (stable) layer especially during the intense polar air outbreak. The vertically uniform distribution of equivalent potential temperature $\theta_{e}$ within the subinversion layer indicates that the air mass is vertically well mixed.

\subsection{Kinematic features}

The vertical time section of the meridional component of wind velocity, $v$, and the vertical velocity, $\omega^{*}$, over area $\mathrm{A}$ is presented in Fig. 4. Strong southerly wind and upward velocity are found on 14 February when the developed cyclone passes over. Strong northerly winds associated with subsidence begin to prevail after the cyclone's passage and continue throughout the cold period. The strong northerly winds prevail not only in the subinversion layer but also above the inversion. The maximum downward velocity is found above the inversion during the cold period. (cf, the cold period of AMTEX '74: Northerly wind and downward velocity decreased rapidly in the inversion layer.)

\subsection{Cloud and precipitation}

Intense rainfall occurred on 14 February when the cyclone passed over AMTEX area. During the cold period, however, precipitation is extremely small over AMTEX area. Fig. 5 shows the distribution of the mean amount of the low cloud whose base is lower than $2500 \mathrm{~m}$ and the precipitation during 3-day period from 12 GMT 20 to 12 GMT 23 February. Fig. 6 indicates the time variation of height of the cloud base, cloud
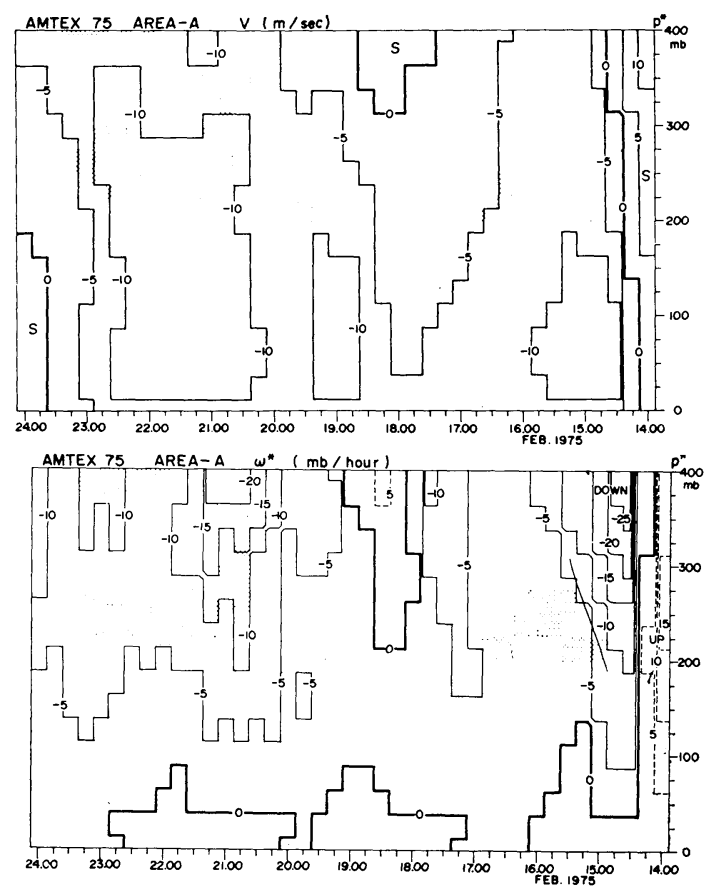

Fig. 4 Vertical time section of meridional component of wind velocity $v$ and vertical velocity, $\omega^{*}$ over area A. The plus (minus) sign of $v$ shows the southerly (northerly) wind and the plus (minus) sign of $\omega^{*}$ the upward (downward) motion. Stipplings show the inversion layer. The abscissa indicates the date and the ordinate $p^{*}$.

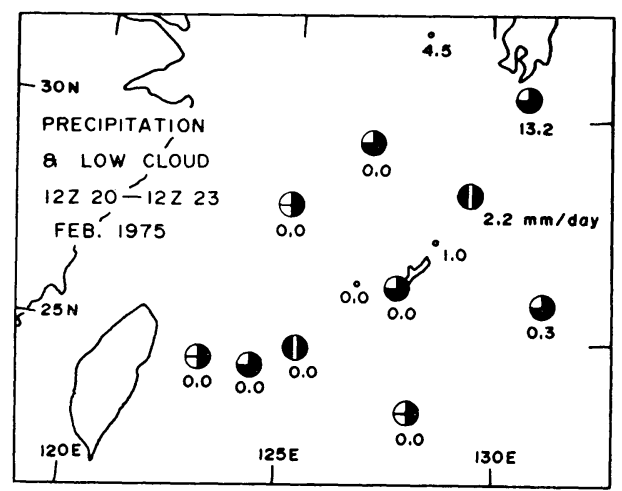

Fig. 5 Mean low-cloud amount and precipitation during 3-day period from 12 GMT 20 to 12 GMT 23 February 1975.

amount and cloud type observed at Naha Aviation Weather Station.

The precipitation during the cold period of AMTEX ' 75 is extremely small $(\sim 0.5 \mathrm{~mm} /$ day $)$ as compared that of AMTEX $74(\sim 5 \mathrm{~mm} /$ day $)$. The amount of low cloud and the height of cloud base are approximately $6 / 8(\sim$ broken $)$ and $700 \sim$ 


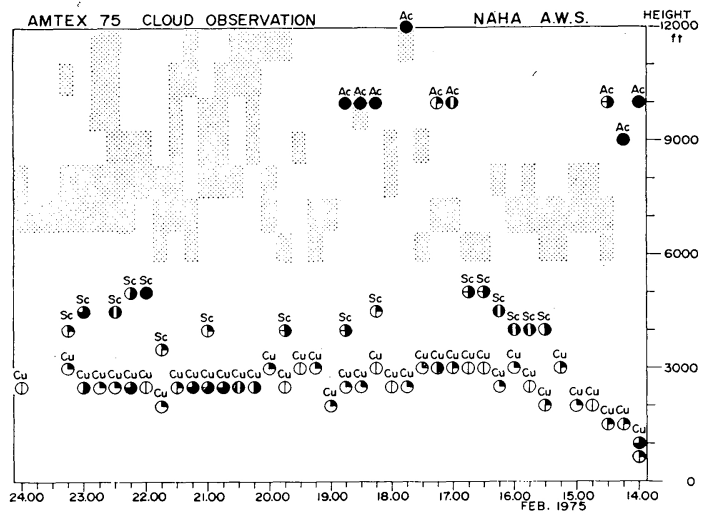

Fig. 6 Time variation of cloud base, cloud type and cloud amount observed at Naha Aviation Weather Station. Stippled area indicates the inversion layer over Naha. The abscissa indicates the date and the ordinate height (feet).

$800 \mathrm{~m}$ respectively during the analyzed period. These values are nearly the same as those in the cold period of AMTEX '74.

\section{Heat energy budget in the cold period of AMTEX 75}

Fig. 7 is the vertical time section of $\delta(T+$ $\left.L / c_{p} q\right) / \delta t$ evaluated over area A. The large value of the total heat energy source $\left(\sim 1.0^{\circ} \mathrm{K} /\right.$ hour $)$ is obtained within the subinversion layer at almost all observation times during the cold period. The total heat energy source shows rapid decrease within the inversion layer.

The amount of the total heat energy supplied from the sea, $F_{c}(\mathrm{sfc})$, is evaluated by the vertical integration of $\left[\delta\left(T+L / c_{p} q\right) / \delta t-d T_{R} / d t\right]$ from $p^{*}$ top at which eddy transport of heat energy vanishes, to the surface (see eq. (9)). The vertical distribution of $d T_{R} / d t$ obtained by Murty (1976) is adopted for the present calculation, though

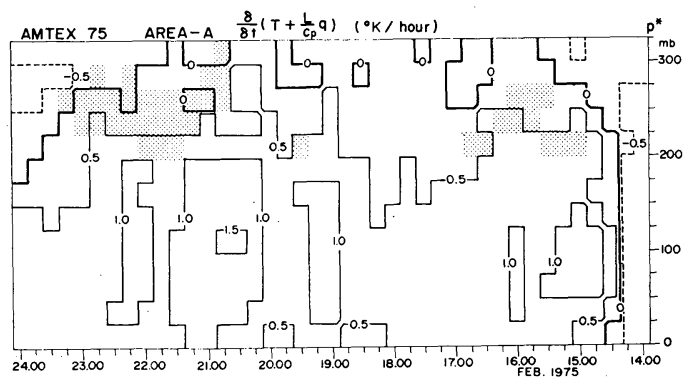

Fig. 7 Vertical time section of apparent total heat source $\delta\left(T+L / c_{p} q\right) / \delta t$ over area A. The plus (minus) sign shows the apparent total heat source (sink). Stipplings show the inversion layer. The abscissa indicates the date and the ordinate $p *$.
Murty's result does not indicate the large cooling rate at the top of cloud layer, such as evidently shown by Kano and Miyauchi (1975). The defect of Murty's result does not affect, however, the whole budget calculation, because $d T_{R} / d t$ is much smaller than $\delta\left(T+L / c_{p} q\right) / \delta t$. As far as the evaluation of $F_{\mathrm{c}}(\mathrm{sfc})$ is concerned, it does not matter whether $p^{*}$ at the inversion base or at the inversion top is taken as $p^{*}$ top in eq. (9), because $\left[\delta\left(T+L / c_{p} q\right) / \delta t-d T_{R} / d t\right]$ is small and varies around zero within the inversion layer. In the present section, $p^{*}$ at the inversion base is taken as $p^{*}$ top for the integration in eq. (9). We evaluate $F_{c}$ (sfc) over areas $\mathrm{A}, \mathrm{B}$ and $\mathrm{C}$ and then calculate an areal averaged value which is presented in Fig. 8. During the analyzed period, except the period of extremely intense polar air outbreak (20 21 February 1975), total heat energy supply varies around $40 \mathrm{ly} /$ hour $(\sim 1000 \mathrm{ly} /$ day $)$ and increases to $\sim 80 \mathrm{ly} /$ hour when the polar air outbreak is extremely intense. The result coincides with that obtained by Kondo (1976) within the noise level.

The aforementioned features of $\delta\left(T+L / c_{p} q\right) /$ $\delta t$ and $F_{c}(\mathrm{sfc})$ are similar to those in the cold period of AMTEX '74 (Ninomiya and Akiyama (1976)). We found, however, a noteworthy difference between the two periods when we evaluated $\delta T / \delta t$ and $\delta q / \delta t$ separately. Fig. 9 is the

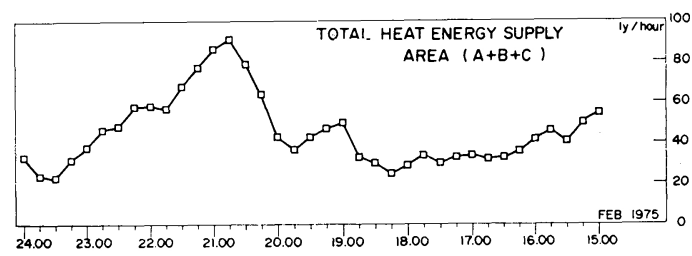

Fig. 8 Time variation of the total heat energy supply averaged over areas A, B and C. The abscissa indicates the date and the ordinate the amount of heat energy supply (ly/hour).

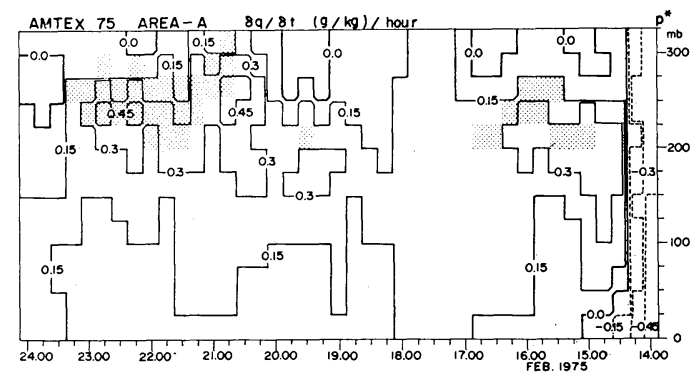

Fig. 9 Vertical time section of apparent moisture source $\delta q / \delta t$ over area A. The plus (minus) sign shows the apparent moisture source (sink). Stipplings show the inversion layer. The abscissa indicates the date and the ordinate $p^{*}$. 
vertical time section of $\delta q / \delta t$ over area A. It is evident that apparent moisture source is large $(\sim 0.3 \mathrm{~g} / \mathrm{kg} / \mathrm{hour})$ around the inversion base at almost all observation times. On the one hand, large apparent heat sink $\left(-0.5 \sim-1.0^{\circ} \mathrm{K} /\right.$ hour $)$ is found around the inversion base, though the figure is not presented. The positive value of $L / c_{p}(\delta q / \delta t)$ and the negative value of $\delta T / \delta t$ cancel out each other and thus $\delta\left(T+L / c_{p} q\right) / \delta t$ results in to be small in the inversion layer as seen in Fig. 8. This would suggest the evaporation from the top of the non-precipitation cloud. We should recall the results by Nitta (1976), Ninomiya and Akiyama (1976) for the cold period of AMTEX '74 that both $\delta q / \delta t$ and $\delta T / \delta t$ almost vanish in the inversion layer.

\section{Three selected period of polar air outbreak}

\section{Selection of the period.}

It is generally known that the evaluation of vertical velocity from the continuity equation at each observation time is not always reliable and the accuracy of $\delta T / \delta t$ and $\delta q / \delta t$ is, sometimes, sensitive to that of $\omega^{*}$ (see eqs. (4) and (5)). In order to eliminate the error at each observation time, we will treat the time averaged values for the "quasi-stationary stage" of the polar air outbreak. Taking account of thermal and kinematic features of the polar air mass, we select Period I from AMTEX '74, Periods II and III from AMTEX ' 75 as listed in Table 1. The detailed description on Period I was already given by Ninomiya and Akiyama (1976).

It is also well known that the result of budget calculations over small domain is not always reliable. In the following sections we will, therefore, average the values evaluated over areas A, $\mathrm{B}$ and $\mathrm{C}$ and discuss only the "mean situation".

\section{Thermal stratification.}

Fig. 10 shows the mean vertical profiles of potential temperature $\theta$, equivalent potential temperature $\theta_{e}$ and mixing ratio $q$ for Periods I, II and III. The most stable layer is found approximately in $200 \sim 300 \mathrm{mb}\left(p^{*}\right)$. Owing to temporal and spatial variations in the height and intensity of the inversion, an actual inversion, such as appears on almost all soundings, is not seen on the mean soundings. The vertically uniform distribution of $\theta_{e}$ within $0 \sim 200 \mathrm{mb}\left(p^{*}\right)$ layer is found commonly for the three periods, though Period II is warmer by $\sim 3^{\circ} \mathrm{K}$ than Periods $\mathrm{I}$ and III. It is noteworthy that mixing ratios in 225 $300 \mathrm{mb}\left(p^{*}\right)$ layer in Periods II and III are smaller than that in Period I by $1.5 \sim 2.0 \mathrm{~g} / \mathrm{kg}$.

\section{Kinematic features.}

Fig. 11 shows the mean vertical profiles of $v$ and $\omega^{*}$ for these periods. Though the strong northerly winds of $\sim 10 \mathrm{~m} / \mathrm{sec}$ in $0 \sim 200 \mathrm{mb}\left(p^{*}\right)$ layer are commonly found for the three periods, the northerly winds in 200 300 mb $\left(p^{*}\right)$ in Period I are very weak as compared with those in Periods II and III. In Period I, northerly wind component shows rapid decrease in the inversion (stable) layer and the westerly current prevails in and above the stable layer though the figure for the zonal wind is not shown here. While in

Table 1. Undisturbed periods of polar air outbreak selected for the comparison.

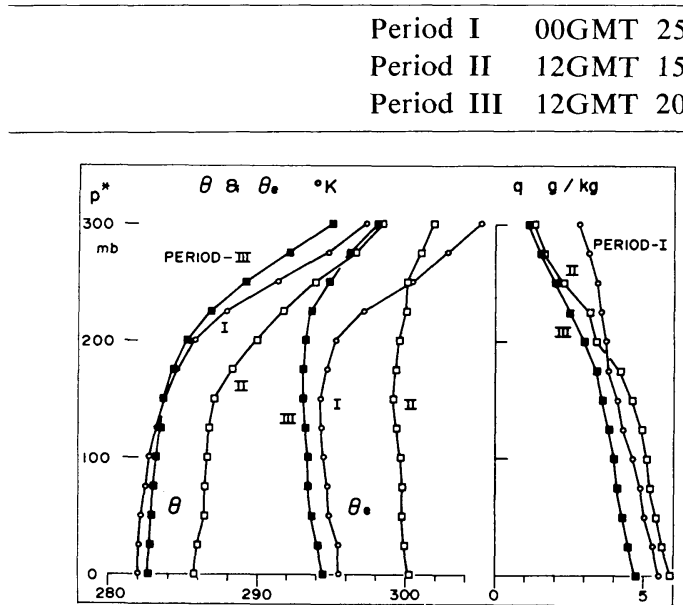

Fig. 10 Mean vertical profiles of potential temperature $\theta$, equivalent potential temperature $\theta_{e}$ and mixing ratio $q$ in Periods, I, II and III.
Periods II and III, northerly component does not decrease within or above the inversion layer.

The well known relation that a large-scale northerly current is accompanied with subsidence is evidently found in Fig. 11. In Period I, the downward velocity exhibits the maximum value below the inversion base and decreases in the westerly layer above the inversion base. While in Periods II and III, the downward velocity does not decrease above the inversion layer.

\section{Precipitation.}

The precipitation in Period I is obviously large as compared with those in Periods II and III. In Period I, precipitation is especially large over the Nansei Islands though the precipitations 


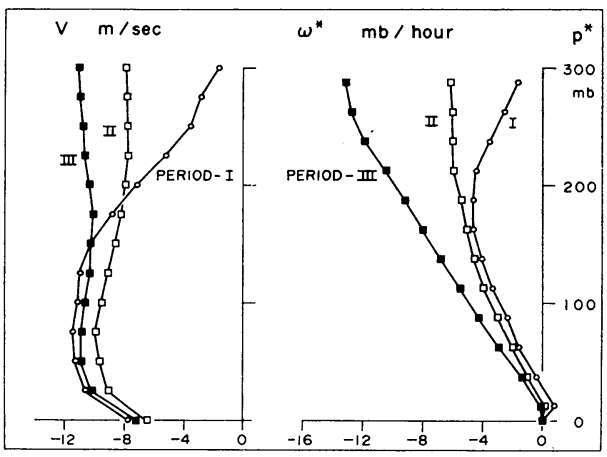

Fig. 11 Mean vertical profiles of meridional component of wind velocity $v$ and vertical velocity $\omega^{*}$ in Periods I, II III. The minus (plus) sign of $v$ shows the northerly (southerly) wind and the minus (plus) sign of $\omega^{*}$ the downward (upward) motion.

measured on the two research ships $K$ and $R$ are small, which were located to the north of the islands. The areal averaged value over the analyzed domain is $4 \sim 5 \mathrm{~mm} /$ day for Period $\mathrm{I}$. In Periods II and III, precipitation is zero at many island and ship stations though "trace of shower" is occasionally reported. The areal averaged value is about $0.5 \mathrm{~mm} /$ day in Periods II and III. (As seen in Fig. 5, large amount of rainfall is observed over the northeastern area outside of the analyzed domain in Period III.)

As to the amount of the low cloud ( broken) and the height of cloud base $(700 \sim 800 \mathrm{~m})$, however, we do not recognize any significant differences among the three periods as far as the cloud reports from the synoptic stations are concerned.

\section{Summary of synoptic situation.}

The characteristics of synoptic features of the three selected periods are summarized in Table 2. In a word, Periods II and III are the periods of the polar air outbreak under conditions of the strong subsidence in the thick layer of northerly winds while Period I is the period of the polar air outbreak under conditions of the weak subsidence in the relatively thin layer of northerly winds. It is also mentioned that Periods II and III are characterized by the non-precipitating cloud layer while Period I by the precipitating cloud layer.

\section{Heat and moisture budget in the polar air mass with strong and weak subsidences}

Figs. 12, 13 and 14 show the mean vertical distributions of apparent total heat energy source $\delta\left(T+L / c_{p} q\right) / \delta t$, apparent heat source $\delta T / \delta t$ and apparent moisture source $\delta q / \delta t$ in Periods I, II and III, respectively. The stipplings in the figures indicate the "mean stable (or inversion) layer", where the mean lapse rate is large than $-0.2^{\circ} \mathrm{C} / 100 \mathrm{~m}$ (that is, $\partial T / \partial Z \geq-0.2^{\circ} \mathrm{C} /$ $100 \mathrm{~m})$. We should note that the base of the "mean stable layer" does not always correspond to an "actual inversion base" seen on each individual sounding, owing to temporal and spatial variations in the height of the inversion base. The lowest 25 or $50 \mathrm{mb}$ of the "mean stable layer" will include some part of the cloud layer at some observation stations at some observation times.

The apparent total heat source exhibits a large value in the lowest $150 \mathrm{mb}$ and shows rapid decrease with height above the base of the mean stable layer. This characteristic feature of $\delta(T+$ $\left.L / c_{p} q\right) / \delta t$ is commonly found in these three periods.

A distinct maximum of apparent moisture source is found in the lower portion of the mean stable layer in Periods II and III, while such a maximum is not seen in Period I. It is also evident that there is a maximum apparent heat sink in the lower portion of the mean stable layer while apparent heat sink is weak in the corresponding layer in Period I.

We next present the vertical distribution of each term in eqs. (4) and (5) in Period III (Figs. 15 and 16) in order to investigate the relation between grid-scale conditions and source terms. The terms of the local time change, $(\partial T / \partial t$ and $\partial q / \partial t$ ), make very small contribution within the analysed layer. In the lowest $150 \mathrm{mb}, V \cdot \nabla T$ (cold advection), $V \cdot \nabla q$ (dry advection) and apparent

Table 2. Characteristic synoptic situation of the selected periods.

\begin{tabular}{lcl}
\hline & subsidence & cloud and precipitation \\
\hline Period I & weak & precipitating cloud layer \\
Period II & strong & non-precipitating cloud layer \\
Period III & strong & non-precipitating cloud layer \\
\hline
\end{tabular}




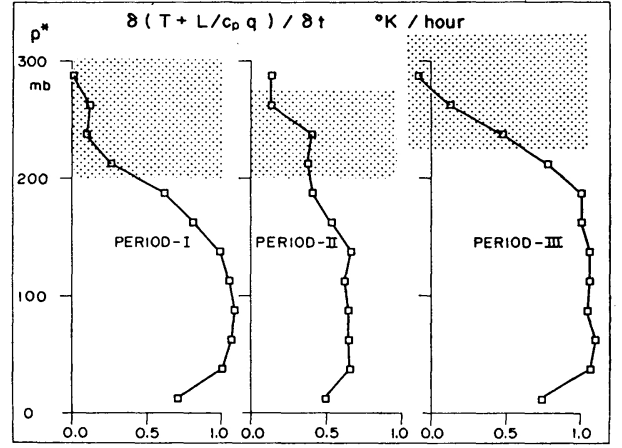

Fig. 12 Mean vertical profile of apparent total heat energy source $\delta\left(T+L / c_{p} q\right) / \delta t$ in Periods I, II and III. Stipplings indicate the "mean inversion (or stable) layer".

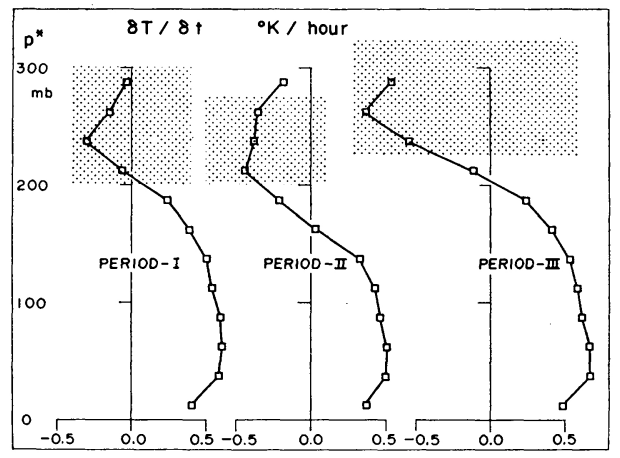

Fig. 13 Mean vertical profile of apparent heat source $\delta T / \delta t$ in Periods I, II and III. Stipplings indicate the "mean inversion (or stable) layer".

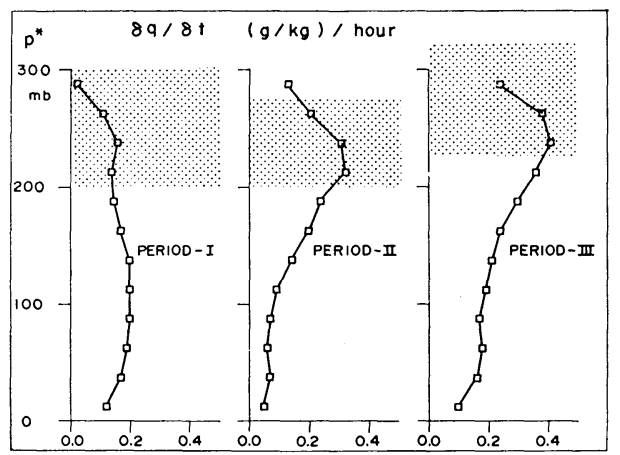

Fig. 14 Mean vertical profile of apparent moisture source $\delta q / \delta t$ in Periods, I, II and III. Stipplings indicate the "mean inversion (or stable) layer".

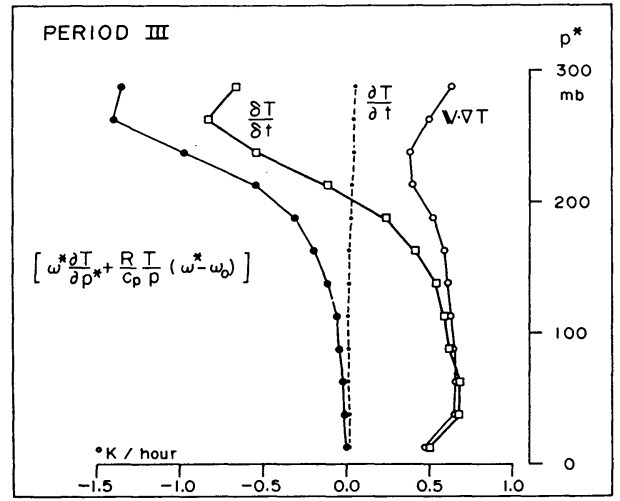

Fig. 15 Mean vertical profile of each term in eq. (4) in Period III.

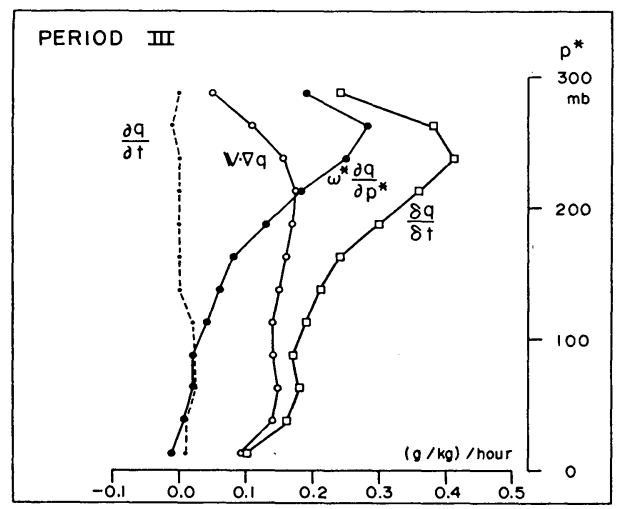

Fig. 16 Mean vertical profile of each term in eq. (5) in Period III.

source terms ${ }^{\dagger}(\delta T / \delta t$ and $\delta q / \delta t)$ are the major terms in heat and moisture balance equations. The features described above coincide well with those in Period I (see Figs. 24 and 25 of Ninomiya and Akiyama (1976)).

In $175 \sim 250 \mathrm{mb}\left(p^{*}\right)$, however, temperature rise due to the subsidence (that is warm vertical advection of potential temperature), $\left[\omega^{*} \partial T / \partial p^{*}+\right.$ $\left.R / c_{p} T / p\left(\omega^{*}-\omega_{o}\right)\right]$, vertical dry advection $\omega^{*} \partial q /$ $\partial p^{*}$, apparent heat sink and apparent moisture source are the major terms. The aforementioned features in $175 \sim 250 \mathrm{mb}\left(p^{*}\right)$ including the inversion base are significantly different from those in the corresponding layer of Period I. The large positive and negative values of $\delta q / \delta t$ and $\delta T / \delta t$

$\dagger$ Eqs. (2) and (3) indicate the physical meaning of apparent source terms. The apparent sources are due to the vertical convergence of eddy heat and moisture flux and the "net condensation". 
and the small value of $\delta\left(T+L / c_{p} q\right) / \delta t$ in the lower portion of the "mean stable layer" imply that the considerable part, at least, of the "cooling" and the "moistening" is due to the evaporation (negative net condensation) from the cloud, though we can not separate the evaporation and the vertical convergence of eddy flux in the present analysis. It is an important finding that the "evaporation" occurs in Periods II and III which are characterized by non-precipitating cloud and strong subsidence. An implication is that the conversion of sinking inversion air into subinversion air is accomplished by the evaporation of cloud tops in the inversion layer.

The vertical extension of the "cloud layer", including the "evaporation layer", and the "mean stable layer" in Period III are, for example, schematically illustrated in Fig. 17.

Now we should recall eqs. (7) and (8) used for the evaluation of sensible and latent heat supplies from the sea. If the "evaporation layer" in the "mean stable layer" is not included within the vertical integration in eqs. (7) and (8), it is obvious from the profiles of $\delta T / \delta t$ and $\delta q / \delta t$ that the latent heat supply $F_{L}(\mathrm{sfc})$ is underestimated while the sensible heat supply $F_{S}(\mathrm{sfc})$ is overestimated and therefore Bowen's ratio is much overestimated. The unreasonably large Bowen's ratio ( 2.9$)$ obtained by Murty (1976) for the cold period of AMTEX '75 would be owing to the exclusion of the "evaporation layer" in the vertical integrations. (Murty decided $p^{*}$ top from the base of the "areal mean stable layer" over the large domain at each observation time.)

At the end of this section, we summarize the results of the budget calculations in the three periods in the schematic diagrams (Fig. 18). The "subcloud layer" in the figure indicates $0 \sim 75 \mathrm{mb}$ $\left(p^{*}\right)$ layer. The "cloud layer" includes both

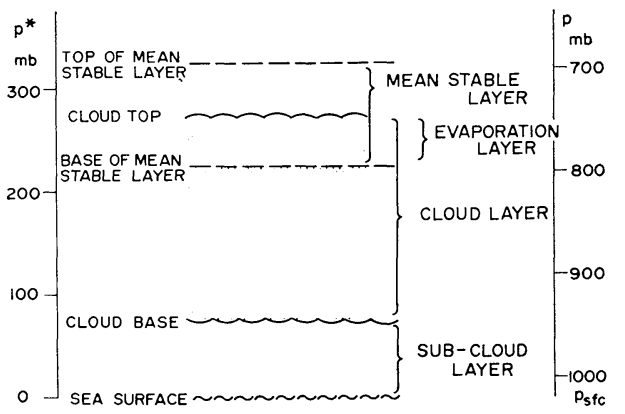

Fig. 17 Schematic illustration of "cloud layer", including the "evaporation layer", and the "mean stable layer" in Period III.
$75 \mathrm{mb} \sim p^{*}$ base (base of the mean stable layer) and the "evaporation layer", that is the lowest $50 \mathrm{mb}$ in the "mean stable layer". For constructing the diagrams, we assume that the amount of effective condensation in the "cloud layer" is equal to the precipitation measured at the surface. We neglect the evaporation from falling water particles in the subcloud layer. The rate of net radiative cooling obtained by Nitta (1976) for AMTEX '74 and by Murty (1976) for AMTEX '75 are adopted for the present diagrams. The amount of total heat energy supply $F_{C}(\mathrm{sfc})=$ $F_{S}(\mathrm{sfc})+F_{L}(\mathrm{sfc})$, Bowen's ratio $F_{S}(\mathrm{sfc}) / F_{L}(\mathrm{sfc})$, ratio $F_{S}$ (cloud base) $/ F_{L}$ (cloud base) and ratio

$$
\frac{C_{p}}{g} \int_{\text {cloud layer }} \frac{\delta T}{\delta t} d p^{*} / \frac{L}{g} \int_{\text {cloud layer }} \frac{\delta q}{\delta t} d p^{*}
$$

are presented in Table 3 .

It is encouraging to find that both the amount of total heat energy supply and Bowen's ratio obtained in the present study coincide well with those evaluated by Kondo (1976) based on the bulk aerodynamic method. The ratio $F_{S}$ (cloud base) $/ F_{L}$ (cloud base), that is "Bowen's ratio at cloud base", is much smaller as compared with Bowen's ratio. It indicates that the eddy transport of latent heat constitutes the dominant contribution to the eddy transport of total heat energy across the base of the cloud layer.

The noteworthy differences between Periods II, III and Period I are found in the "cloud layer". In the non-precipitating cloud layer under the strong subsidence (Periods II and III) effective condensation is very small and apparent latent heat source is very large as compared with apparent sensible heat source. On the one hand, within the precipitating cloud layer (Period I),

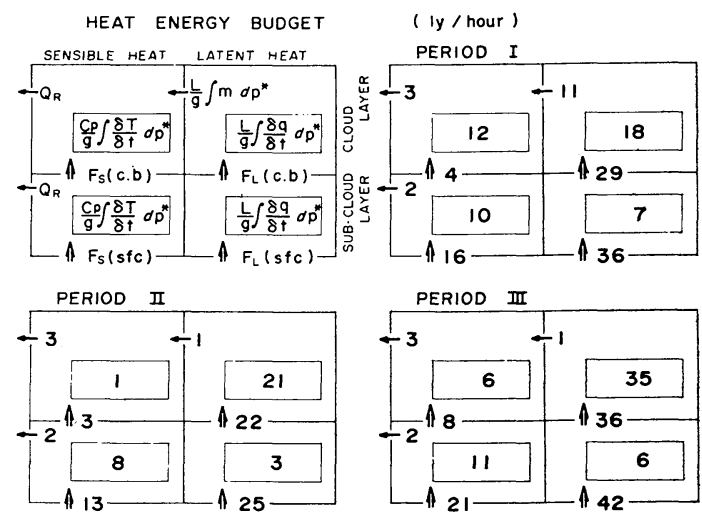

Fig. 18 Schematic diagram summarizing the heat energy budget situations in sub-cloud layer and cloud layer in Periods I, II and III. 
Table 3. Results of the budget calculations

\begin{tabular}{lccc} 
& Period I & Period II & Period III \\
\hline$F_{S}(\mathrm{sfc})+F_{L}(\mathrm{sfc})$ & 52 ly/hour & 38 & 63 \\
Bowen's ratio & 0.14 & 0.52 & 0.22 \\
$F_{S}$ (cloud base) $/ F_{L}$ (cloud base) & 0.14 & 0.14 & 0.22 \\
$\frac{C p}{g} \int_{\substack{\text { cloud } \\
\text { layer }}} \frac{\delta T}{\delta t} d \rho^{*} / \frac{L}{g} \int_{\substack{\text { cloud } \\
\text { layer }}} \frac{\delta q}{\delta t} d p^{*}$ & 0.67 & 0.05 & 0.17 \\
\hline
\end{tabular}

effective condensation convertes considerable portion of latent heat energy to sensible heat energy and therefore apparent sensible heat source is comparable to apparent latent heat source.

It is an important fact that the amount of the total heat energy supplied from the sea and Bowen's ratio obtained in Period III are approximately equal to those in Period I. The largescale subsiding motion, therefore, is supposed to be the crucial factor to control heat and moisture balances in the cloud layer capped by the inversion layer.

The situations found in Periods II and III are somewhat resemble to the situations in a period of undisturbed trade wind inversion (cf., Holland and Rasumsson (1973), Nitta and Esbensen (1974)).

It is desirable, if possible, to construct a budget diagram for the three layers, i.e., the subcloud layer, the lower cloud layer in which the "net condensation" occurs and the "evaporation layer" for the further understanding. For this purpose it is required to evaluate "vertical convergence of eddy transport of heat and moisture" and "net condensation" separately in each layer. To do so, we need certain assumptions or theories such as used by Yanai et al. (1973) and Nitta (1975), though we do not intend to make such a sort of analysis in the present paper.

\section{Concluding remarks}

The atmospheric heat energy budget over the Kuroshio region has been analysed for the cold period in AMTEX '75. The situations of this period are somewhat different from those in AMTEX ' 74 described in Ninomiya and Akiyama (1976).

Three undisturbed periods of polar air outbreak are selected for the detailed comparison. These are Period I (25 27 February 1974), Period II (15 16 February 1975) and Period III (20 23 February 1975).

The large-scale features of Periods II and III are characterized by non-precipitating cloud layer capped by the inversion which developed under conditions dominated by a strong subsidence, while those of Period $\mathbf{I}$ are characterized by precipitating cloud layer capped by the inversion which separates the weak subsiding northerly layer from the westerly layer aloft.

The large apparent heat and moisture sources in the subinversion layer are commonly found for the three periods. The situation in 175 $250 \mathrm{mb}\left(p^{*}\right)$ layer in Period $\mathrm{I}$ is, however, obviously different from that in Periods II and III. In Period I, both apparent heat and moisture sources show rapid decrease above the inversion. In Periods II and III, large apparent moisture source and large apparent heat sink are found above the base of "mean stable layer". This feature resembles to that of the undisturbed trade wind inversion and suggests the evaporation from clouds. The conversion of sinking inversion air into subinversion air would require the evaporation of clouds in the inversion layer.

The results of the present analysis evidently indicate the controlling influence of the largescale subsidence upon the heat and moisture balances in the cloud layer of the transformed polar air mass over the Kuroshio region.

The determination of cloud mass flux, entrainment, detrainment and the associated transport of heat energy and the investigation on their response to the large-scale condition, such as presented by Yanai et al. (1973), and Nitta (1975) for the trade region seem to be useful for the further understanding of the air-mass transformation over AMTEX region, though we did not intend this sort of analysis in the present study.

In the present analysis, the horizontal advection of the cloud particles (or water substance in more general) is not taken into ascount. However the budget analysis by Matsumoto and Ninomiya (1966) over the Japan Sea suggested the importance of this term in the budget study. Therefore, the inclusion of the advection of water substance would be desired for the future study. 


\section{References}

Holland, J. and E. M. Rasmusson, 1973: Measurements of the atmospheric mass, energy and momentum budgets over a 500-kilometer square of tropical ocean. Mon. Wea. Rev., 101, 44-55.

Kano, M. and M. Miyauchi, 1975: On the infrared radiative flux and cooling rate in the cloud atmosphere. Scientific Report of 4th AMTEX Study Conf. 51-53.

Kondo, J., 1976: Heat balance of the East China Sea during the Air-Mass Transformation Experiment. J. Met. Soc. Japan, 54, 382-398.

Matsumoto, S. and K. Ninomiya, 1966: Some aspects of the cloud formation and its relation to the heat and moisture supply from the Japan Sea surface under a weak winter monsoon situation. J. Met. Soc. Japan, 44, 60-75.

Murty, L. K., 1976: Heat and moisture budgets over AMTEX area during AMTEX '75. J. Met. Soc. Japan, 54, 370-381.

Ninomiya, K., 1976: Note on synoptic situation of AMTEX '75. J. Met. Soc. Japan, 54, 334-337. and T. Akiyama, 1976: Structure and heat energy budget of mixed layer capped by inversion layer during the period of polar outbreak over Kuroshio region. J. Met. Soc. Japan, 54, 160-174.

Nitta, T., 1975: Observational determination of cloud mass flux distributions. J. Atmos. Sci., 32, 7391.

-, 1976: Large-scale heat and moisture budget during the Air-Mass Transformation Experiment. J. Met. Soc. Japan, 54, 1-14. - and S. Esbensen, 1974: Heat and moisture budget analyses using BOMEX data. Mon. Wea. Rev., 102, 17-28.

Rasmusson, E. M., 1971: Mass, momentum and energy budget equations for BOMAP computations. NOAA Technical Memorandum, ERL, BOMAP-3, 32 pp.

Saito, N., 1975: A synoptic study of the inversion during the AMTEX '74. Pap. Meteor. Geophy., 26, 121-147.

Yanai, M., S. Esbensen and J. H. Chu, 1973: Determination of bulk properties of tropical cloud clusters from large-scale heat and moisture budgets. J. Atmos. Sci., 30, 611-627.

\section{黒潮海域での著しい沈降をともなう寒気の気団変質の熱収支}

\section{二宮 洸 三 気象研究所}

AMTEX 75 の寒気吹出時の詳細な解析を行った。寒気の振舞・熱収支状況は AMTEX 74 のそれとかなり異っ た様相を示していた。準定常的な寒気吹出期間，すなわち，Period I (1974 年 2 月 25〜27 日), Period II (1975 年 2月 15〜16 日）および Period III（1975 年 2 月 20〜23 日）を選び，この期間の状況を比較する。

Period I の総観気象状況は, 下層 $(\sim 2 \mathrm{~km})$ の北風と上層の西風を境する逆転層, 逆転層下に極大をもつ弱い沈 降および逆転層下の降水（～5 mm/day）をともなら雲層によって特徵ずけられる。Period II・III 泣，厚い北風層 と著しい沈降, 逆転層下の降水をともなはない雲層によって特徴ずけられる。

subinversion layer で大きな apparent heat source, moisture source $(\delta T / \delta t$ と $\delta q / \delta t)$ がみられる事は, 3 期 間の共通した状況であるけれども，逆転層下面を含む $175 〜 250 \mathrm{mb}\left(P^{*}\right)$ 層の状沉については Period I と， II ・ III は著しく異なる。Period I については, $\delta T / \delta t, \delta q / \delta t$ とも，逆転層内で減少を示し，小さな值しかもたない。

Period II・III では, 逆転層下部で $\delta q / \delta t$ の極大と, 負の $\delta T / \delta t$ (heat sink) の極大があらわれる。しかも，この 部分では $\delta\left(T+L / C_{p} q\right) / \delta t$ の值は極めて小さい。これは, 降水をともなわない雲の上部での蒸発を意味するであろら が，これが強い沈降にともなってのみ見出されたのは注目される。すなわち，著しい気団の沈降は，乾いた逆転層の 空気を, 湿った subinversion layer に送りこむが, これが雲頂からの蒸発とバランスしている。（雲は気団変質に 関係して発生していることは云らまでもない。)

この解析で得られた, 熱エネルギー補給量（～10001y/day), Bowen's ratio ( 0.5) は Kondo (1976) の bulk 法によるものと良く一致している。Murty (1976) による AMTEX 75 の寒気吹出時の，大きすぎる Bowen's ratio (〜0.9) は“雲層からの蒸発層”が計算から除外されたためだと推論される。

Period I と III の間には, 海面からの補給量に関しては本質的な差のなかったことから考えて, 大規模な沈降の 気団変質に対する影響は極めて大きなものだと思はれる。

この解析の結果は, 黒潮海域の寒気吹出時の気団変質における, 降水をともなら雲層と, ともなわない雲層との熱 力学的バランスの差異と大規模な沈降の気団変質過程に対する影響を明示したものである。 